\title{
Ethical communication and intercultural responsibility: a philosophical perspective
}

\section{Giuliana Ferri}

The ethical dimension of dialogue represents a major concern in the context of current research in intercultural responsibility. In this paper, I discuss the modalities in which the notion of competence is used to conceptualise responsibility and the relationship between self and other in intercultural research, in order to critique the Cartesian presuppositions of intercultural communication theory. I argue that models of competence and responsibility that are employed to design intercultural training operate within the paradigm of the autonomous rational agent that informs Kantian ethical thinking. I contrast the model of the competent intercultural speaker that emerges in intercultural research with the distinction proposed by Levinas between the saying and the said (le dire and le dit, meaning the event of speech and the content of speech), to suggest two scenarios of intercultural interaction that show two different approaches to responsibility, one operating in the dimension of the said and the other in the dimension of the saying. Thus, in this paper, I discuss the implications of Levinas's reflection on the nature of language for the development of an ethical framework that addresses the limitations of current conceptualisations in intercultural communication theory of competence and responsibility.

La dimensione etica del dialogo rappresenta una delle preoccupazioni maggiori nell'ambito della ricerca sulla responsabilità interculturale. In questo articolo analizzo in maniera critica le modalità in cui la nozione di competenza è usata per concettualizzare il concetto di responsabilitá e la relazione con l'altro nel contesto della teoria della comunicazione interculturale, in modo da discuterne le presupposizioni Cartesiane. I modelli di competenza e responsabilità che sono utilizzati nel training interculturale operano all'interno del paradigma dell'agente autonomo razionale della tradizione etica kantiana. Ho intenzione di contrastare il modello del "competent intercultural speaker" che emerge dalla ricerca interculturale con la distinzione creata da Levinas tra il dire e il detto (le dire e le dit, l'evento della parola e il contenuto della lingua), per suggerire due scenari di interazione interculturale che mostrano due approcci alla responsabilitá, uno nella dimensione del dire e l'altro nella dimensione del detto. Quindi, in questo articolo discuto le implicazioni delle riflessioni di Levinas sulla natura del linguaggio per lo sviluppo di una comprensione etica che riconosce i limiti delle concettualizzazioni delle nozioni di competenza e responsabilità nella teoria della comunicazione interculturale. Keywords: ethical communication; responsibility; Levinas; intercultural competences; language learning.

\section{Introduction}

This paper is theoretical and exploratory in nature. Its aim is twofold: to describe the models of competence developed in the field of intercultural communication, and to introduce the categories of the said, meaning the content of speech, and the saying, which indicates the event of speech, elaborated by Levinas (1998). Using this distinction, I discuss the modalities in which the notion of competence is used to conceptualise responsibility and the relationship between self and other in intercultural research, and I suggest two scenarios of intercultural interaction, one operating in the dimension of the said and the other in the dimension of the saying. In doing this, I describe the ethical relation formulated by Levinas $(1969,1985,1998,2006)$ to define the encounter with the uniqueness of the other through the open-ended character of dialogue, in order to critique the Cartesian presuppositions of intercultural communication (henceforth IC) theory. My contention is that models of competence and responsibility that are employed to design intercultural training (e.g. 
Deardorff, 2006, 2009; Guilherme, Keating, \& Hoppe, 2010; Hofstede \& Hofstede, 2004; SpencerOatey \& Stadler, 2009) reflect the Kantian notion of the rational autonomy of the moral agent who is held accountable for the effect of his/her moral decisions on others, who become the recipients of his/her actions. The locus of this agency is the Cartesian subject of the 'I think', a bounded individual capable of autonomy and rationality, a concept that developed during the Enlightenment, and particularly through Kantian moral philosophy, with the internalisation of reason and judgement in the thinking subject according to universal norms of freedom and equality. In other words, the subject of this form of rationality that initiated the modern conception of ethical thinking is able to choose the right course of action according to what reason dictates (Furrow, 2005; Popke, 2003). My argument develops as follows: in the first section, I begin with a reflection on the origins of interculturalism as a field of inquiry in North American foreign policy and trade, which informs a functionalist understanding of communicative competence as effective transmission of meaning across cultures (Martin \& Nakayama, 2010). After touching upon critical formulations of intercultural competence in the context of language learning, I outline current research on the acquisition of communicative competences relating to the development of intercultural responsibility. Finally, I trace the connection that is established in intercultural research between the acquisition of communicative competences and the development of responsibility to the idea of the autonomous rational agent that informs Kantian ethical thinking. In contrast to the model of the competent intercultural speaker that emerges in intercultural research, I intend to discuss the implications of Levinas's reflection on the nature of language for the development of an ethical framework that addresses the limitations of current conceptualisations in intercultural communication theory of competence and responsibility.

\section{The field of intercultural research}

The origins of IC as a field of inquiry in North American foreign policy and trade inform the idea of communication as effective transmission of meaning across cultures. The genealogical reconstruction of the field of IC conducted by Moon (2010) attributes the narrow understanding of culture in terms of national boundaries and the preference for microanalysis focused on communicative practices between interactants from different national cultures, to the agenda set by the US Foreign Institute in the 1950s in order to create intercultural training to use in trade with foreign countries. Moon concludes that:

Intercultural communication developed in the midst of World War II as a tool of imperialism and that much of its foundations were infused with a colonial perspective. $(2010$, p. 35)

Moon attributes the formulation of the concepts of adaptation and competence to this dominant intercultural discourse that has narrowed the field of research to a set of categories that are based on the dichotomy self/cultural other. A significant consequence for intercultural studies is the development of competence training with its practical applications in a variety of contexts. In research conducted in this field (e.g. Berardo \& Deardorff, 2012; Deardorff, 2006, 2009; Hammer, Bennett, \& Wiseman, 2003; Hofstede, Pedersen, \& Hofstede, 2002; Spitzberg \& Changnon, 2009), the ideal of an intercultural performer who can apply the skills of intercultural training in a number of contexts, such as education, management, tourism and intercultural mediation, contributes to the creation of what can be defined as an intercultural industry. An illustration of this intercultural industry is represented by the research of Hofstede (2001) on cultural difference, which offers a model of training in intercultural contexts that reduces culture to a pattern of standardised models of behaviour. The principal claim is that knowledge of behavioural patterns pertinent to a culture, or a cluster of cultures, reduces stress, anxiety and miscommunication in intercultural encounters. A particular essentialist feature is the opposition between individualism and collectivism, the former 
considered a value characteristic of Western societies that nurtures initiative and critical thinking, whilst the latter promotes reliance on tradition and group cohesion typical of Eastern cultures. From a similar perspective, Hall (1995) delineates two main dimensions of culture: high/low assertiveness and high/low responsiveness, so that each style is seen as conforming to a specific national culture. Behind the neutrality of academic research, these values are ideologically attributed to a fundamental, yet unproven difference between freedom in Western societies and the sacrifice of the individual to cultural values in all other societies. According to Jack (2009) this form of interculture is hegemonic, in the sense that this partial and simplified understanding of culture has become a dominant paradigm, assuming the posture of scientific truth. The idea of cultural differences in communication is thus used in guiding communicative exchanges in elite situations, such as business and management, in which recognition of the other is essentialised. Martin and Nakayama (2010) describe hegemonic interculturalism within a functionalist paradigm deriving from post-positivist social psychological research (e.g. Barnett \& Lee, 2002; Gudykunst, 2003), that focuses on consciousness and on the competences of the intercultural speaker in terms of acquisition of skills, effectiveness and appropriateness in language use. In this context, Wiseman's definition of intercultural competence is illustrative of the functionalist paradigm:

ICC competence involves the knowledge, motivation and skills to interact effectively and appropriately with members of different cultures. (2003, p. 192)

This ability is further described as the process of identifying "meanings, rules and codes for interacting appropriately" (p. 200). According to Wiseman, this epistemological approach to competence is accompanied by another ontological dimension that foregrounds the dialectical process of negotiation of separate cultural identities in the course of interaction. In this sense, epistemological factors, including awareness of the other culture, self-awareness and knowledge of the language of interaction, contribute to the successful negotiation of cultural identities that results in competent and effective communication. For example, in Deardoff's model of competence (2006, 2009), the goal of intercultural communication is to communicate effectively and appropriately, showing adaptability and flexibility in selecting appropriate and effective styles that are culturespecific, reflecting the culture of the other relative to the context of interaction. Blommaert $(1991,1998)$ highlights this preoccupation with the practical applications of IC to education, training and management, which leaves unproblematised the notion of culture and the power dimension at work in intercultural communicative exchanges. Similarly, Scollon and Scollon (1995), and Piller (2011) claim that the influence of culture is often inflated in determining behaviour and communication, hiding the socioeconomic inequality that underlies the urban, multicultural and multilingual contexts in which much intercultural communication takes place. From this perspective, Roy and Starosta (2001) argue that a positivist and scientist approach is counter-productive when applied to human sciences, particularly intercultural communication, because it essentialises cultural identity, whilst ignoring the political, social and economic factors that determine the context of interaction. Furthermore, Curtin (2010) positions intercultural competences within the broader ideological and structural contexts in which they are "enacted, judged and challenged" (p. 279), thus problematising competence intended in terms of performance, effectiveness and appropriateness. From a similar critical perspective, Cheng (2010) and DeTurk (2010) problematise the focus on competence training in order to facilitate intergroup dialogue as the process of reinforcing dominant discourses. An illustrative example of this form of essentialism is the intercultural project Global People, which provides guidance in developing intercultural awareness and competence in international educational contexts. In the competency framework delineated by Spencer-Oatey and Stadler (2009), the formulation of competence in terms of acquisition of effective and appropriate communicative skills recalls the neo-essentialism that Holliday (2011) ascribes to the use of language 
of scientific neutrality in relation to culture and communication. In this excerpt, the acquisition of effective and appropriate communicative skills is presented as an essential pre-requisite in building trust and mutual understanding in international exchanges:

One of the key resources we bring to building trust and mutual understanding with our international partners is the quality of our communication skills. We may have come to some useful initial conclusions about what they want and how they operate, but unless we can build on this through effective and appropriate communication strategies and skills, the potential for building shared meaning will be lost. Often international partnerships can be beset by misunderstandings based on problems in overcoming the language barrier as well as a failure to draw on the right mix of listening, speaking and perceptiveness skills in order to construct, explore and negotiate meaning. Often people underestimate the amount of background information that is required to be shared up-front to create a platform for mutual understanding, as well as the different styles needed for communicating effectively with their international partners. (Spencer-Oatey \& Stadler, 2009, p. 5)

This model of competence is built on previous knowledge of communicative styles and behavioural patterns in order to direct the ability to frame interlocutors within a national tradition. What transpires from these formulations of communicative competence is the possibility to achieve a form of transparent communication once the cultural other has been identified and categorised, marginalising the crucial task of intercultural studies to highlight the processual character of communication as an activity that is always situated and negotiated between speakers in both intercultural and intracultural situations (Dervin, 2011). Phipps $(2007,2010)$ critiques the idea of the acquisition of intercultural competence as a quick fix to resolving conflict and misunderstanding, and the practices of the intercultural industry, or "consciousness raising industry" (Phipps, 2013, p. 10), in directing intercultural communication research towards the production of training courses and manuals that offer practical applications and ready-made solutions to the complex endeavour of human understanding. Instead, Phipps emphasises the complexity of communication and 'the mess of human relatedness in languages' $(2007$, p. 26). In this context, the emergence of theoretical interventions that challenge the divide self/other along cultural lines signals the movement towards a redefinition of intercultural communication beyond current models of acquisition, assessment and reliable testing of communicative competences. The post-structuralist approach of Monceri (2003, 2009) rejects culture as the principal model to understand and explain behaviour, emphasising flux and becoming over cultural categorisation. Similarly, Dervin $(2010,2011)$ employs the concept of'space-time' instead of the word culture, in reference to Bauman's(2000) liquid modernity, meaning that culture is always situated, and as such, it is a joint construction between self and other shaped by the context of interaction.

The competence model in critical intercultural language pedagogy Byram (2008) addresses critically the priority accorded to the teaching of English over other languages, which drives formulations of communicative competence in terms of the hegemonic interculturalism outlined in the previous section. In his words, learning a foreign language is now almost synonymous with learning English:

The role of English thus often dominates the development of language education policies and the teaching of English has been a major influence on the methods of teaching all foreign languages. (Byram, 2008, p. 9)

Furthermore, the prevalent version of English used in international exchanges is Business English, considered a lingua franca in intercultural business communication (Jack, 2009; Louhiala-Salminen, Charles, \& Kankaanranta, 2005). From this perspective, Hüllen (2006) contrasts the utilitarian motivation for learning English as a foreign language to intercultural language learning, outlining a 
notion of competence that takes into account the socially constructed nature of culture and the context of interaction. This latter understanding of competence is illustrated by Byram's model of Savoirs (Byram \& Zarate, 1997a, 1997b), which was influential in the development of the common European Framework of Reference for Languages (Council of Europe, 2001). In this model, the intercultural speaker acquires communicative competence not by casting off his or her social identity in the pursuit of a model of native speaker competence, but by developing the ability to assess the relationship between cultures and mediate between them. This is particularly evident in the case of non-native speakers communicating through a third language, or lingua franca, which increases complexity in communication (Byram \& Risager, 1999). Similarly, Phipps and Gonzalez (2004) introduce the notion of languaging to highlight the complex nature of culture and the role of language in shaping social environments. According to the authors, the intercultural skill of languaging enables negotiation, understanding and transformation in the figure of the languagers-inaction, intercultural beings that cross borders and engage reflectively with self and other. Guilherme (2010) also draws on the notion of situatedness, recognising the necessity to develop a form of competence appropriated to context in order to facilitate communication and understanding in multicultural settings. However, despite the transnational paradigm of Risager (2006), the redefinition of intercultural competence and language learning in terms of critical intercultural citizenship (Byram, 2008; Guilherme, 2002), and the notion of languaging (Phipps \& Gonzalez, 2004), I agree with Dervin (2010) that critical models of intercultural competence are far from becoming embedded in the practice of language teaching. Indeed, learning a foreign language still rests on the idealised notion of the nation state, built on the ideal of a common language and of a native speaker reflecting a homogeneous national culture opposed to other national identities (see the notion of imagined communities in Anderson, 1991; the unproblematic use of the word 'foreign' in language teaching and learning in Pavlenko, 2003; and the description of the national paradigm in language and culture pedagogy in Risager, 2008). The origins of this national paradigm in German Romanticism in the late Eighteenth and early Nineteenth centuries is a well-rehearsed argument (e.g. Hardcastle, 1999; Risager, 2006); therefore, I will only mention von Humboldt's(1988) and Herder's conceptualisation of language as connecting individual consciousness to the wider cultural and spiritual life of a nation, promoting the educational value of the ability to establish comparisons between different peoples and cultures, both past and present, through the study of other languages. This ability formed an important part in von Humboldt's educational ideal of Bildung as personal and cultural maturation, based on the Kantian presupposition of the value of moral qualities in the development of the individual, and it is powerful to this day in shaping national educational policies (Hardcastle, 1999). Kramsch (2009) addresses critically both national cultural paradigms and the understanding of communication as information exchange with the idea of symbolic competence. In this model of competence, the reality of computer-mediated communication and the simultaneous coexistence of different languages and other signifying practices in everyday life displace traditional spatial/temporal positioning. These signifying practices are referred not only in terms of different linguistic codes, but include all the semiotic resources that contribute to the making of a hybrid identity and allow multilingual speakers to appropriate and manipulate multiple symbolic systems. This symbolic entity is formed in interaction with the environment through the discursive practices of others, which are then re-appropriated through the conscious activity of interpretation of signs and symbolic forms and the unconscious activity mediated by the conative sphere involving emotions, feelings, memories and desires. Kramsch attributes the construction of the self to this complex process of interaction:

We only learn who we are through the mirror of others, and, in turn, we only understand others by understanding ourselves as Other. (2009, p. 18) 
In other words, according to Kramsch, the process of acquiring symbolic competence entails a decentering of the self. I adopt this idea of decentering of the self to suggest that research on competence described in reference to Deardorff (2006, 2009), Hofstede (2001), Spencer-Oatey and Stadler (2009) and Wiseman (2003), as well as the model of responsibility delineated in Guilherme et al. (2010) which I describe in the next section draw on the philosophical tradition of the autonomy of the individual. Thus, the relationship self/other is posited in terms of tolerance, leaving open the question of critical engagement and dialogue with differing ethical frameworks in intercultural encounters.

\section{Communicative competence and intercultural responsibility}

Guilherme et al. (2010) describe intercultural responsibility in terms of "a dimension that aims to go beyond a straightforward notion of intercultural competence" (p. 79). Whereas intercultural competence provides the tools to communicate "appropriately and effectively across cultures" (Guilherme et al., 2010), responsibility adds an ethical layer to intercultural interaction. According to the authors, if communicative competence prevents conflict and misunderstanding due to a lack of cultural awareness, intercultural responsibility introduces respect of the other culture and of a different ethical framework. In their words, responsibility also contains an emancipatory aspect that develops from the exercise of intercultural ethics framed within the concept of global ethics, an approach that seeks to reconcile and balance universalistic and relativistic perspectives. This process happens through an ontological shift, a process of discovery and awareness that causes a change in being, transforming the individual into an "intercultural mobile being" (Guilherme, 2010) or an'intercultural personhood' (Kim Yun, 2008). As a result of this critical cycle that causes the ontological transformation, difference is not only perceived in the cultural other, but it is also recognised within intra-cultural contexts and within the individual. The final outcome of this epistemological and subsequent ontological shift is the development of responsibility, the ability to interact effectively and to respect the other culture and a different ethical framework, leading to the acquisition of tolerance, which Guilherme describes as "a psychological readiness to be empathetic and to control one's emotions, that is, to be patient and tolerant towards the other" $(2010$, p. 8). In this description of responsibility, the intercultural personhood is able to forsake both particularistic ethical perspectives and a superficial, or even opportunistic, acknowledgement of difference for instrumental purposes in the name of intercultural dialogue. This is accompanied by the claim that a flexible approach to ethical dilemmas achieved through intercultural responsibility will balance relativistic and universalistic perspectives, leading to emancipatory citizenship and the "corresponding re-framing of institutions and organisations" (Guilherme, 2010, p. 81). The form of responsibility, advocated by Guilherme, Keating and Hoppe with particular reference to multicultural workplaces, demands that:

Every member is responsible not only for identifying and recognising the cultural idiosyncrasies of every other member-in-interaction, but also for developing full and reciprocally demanding professional relationships with them. $(2010$, p. 79$)$

In this context, the principal elements that allow the negotiation of conflicting and relativistic viewpoints, promoting intercultural responsibility, are represented by coherence, empathy and solidarity, described as the ability to work in a collaborative attitude to others and to adapt ethical principles to interactional contexts whilst maintaining 'underlying moral principles' (Guilherme et al., 2010, p. 79). From this standpoint, an intercultural being is able to interact using effective communicative strategies that display a degree of intercultural competence in handling difference, shifting perspective, adopting the viewpoint of the other and negotiating differing values. As a consequence, intercultural communication aims to reduce uncertainty in communicative exchanges 
when difficulties in establishing dialogue are attributed to culture, with the resulting differences in styles of communication. In this regard, responsibility in communication is translated as the acquisition of intercultural competences in communicating with other speakers from different cultural backgrounds, negotiating between differing ethical frameworks. However, the emphasis placed on transformation and dialogue over the simple acquisition of competences is problematic, because the other is still identified with a foreign language and culture, and responsibility emerges as tolerance of the other. In this sense, this account of responsibility reflects Holliday's(2011) description of neoessentialist intercultural research, characterised by the use of the category of cultural difference to analyse the dynamics underlying intercultural communication, initiating a process of othering, or the creation of the dichotomy between the self and the cultural other. This dichotomy is further illustrated in relation to the ethical tradition of autonomy in moral philosophy, which I delineate in the next section in contrast to Levinasian ethics.

\section{Kantian ethics and Levinasian ethics}

Kant (1979) defines ethics as a theory of virtue, based on the strength of self-mastery with respect to the moral disposition, and distinguishes between pure and practical reason, the former concerning knowledge and the latter the conduct of beings possessed of free will. Kantian ethics formulates morality in terms of autonomy and redefines the relationship between individuals and society in terms of self-governance of the individual (Atwell, 1986; Schneewind, 1998). A crucial aspect of Kantian autonomy is that, as part of the noumenal realm (i.e. the realm of the thing-in-itself, unknowable to human experience), freedom is intended in transcendental terms, which means that moral action is not the result of natural causation. On the contrary, moral action follows instead the categorical imperative, a categorical obligation not influenced by the pull of desires and interferences from the sensible world. Providing a comprehensive review of the subsequent developments of the role of autonomy and reason in moral philosophy falls outside the scope of this paper. To this end, I will describe two approaches to ethical thinking that are relevant in order to introduce Levinasian ethics: critical theory and the postmodern turn. The critique of the Enlightenment, started with Adorno and Horkheimer in the Frankfurt School, focused on the notion of the abstract transcendental subject, particularly the identification between instrumental reason and the ensuing understanding of human action as determined by utilitarian motives and the imperative of self-preservation:

The self (which, according to the methodical extirpation of all natural residues because they are mythological, must no longer be either body or blood, or soul, or even the natural I), once sublimated into the transcendental or logical subject, would form the reference point of reason, of the determinative instance of action. (Adorno \& Horkheimer, 1997, p. 29)

The second generation of critical theory, starting with Habermas, rediscovered the Enlightenment project with a critique of instrumental reason and of the self-founding Cartesian subject, through an appreciation of the role of reason understood in the relation to its historical, social and embodied incarnations (Habermas, 1987; Jacobs, 2001). This project of revaluation, based on the notion of communicative ethics that Habermas envisaged in situated reason, is realised in the communicative practices of ordinary interactions oriented to mutual understanding (Habermas, 1987). The other approach to ethical thinking, the postmodern turn, highlighted the principal argument of Dialectic of Enlightenment (Adorno \& Horkheimer, 1997), the role of reason in excluding the 'other' of thinking in the name of uniformity and sameness (Honneth, 1995). This attention towards the heterogeneous, the non-identical and the excluded from the self-transparency of the Cartesian Self represented the starting point of postmodern ethical thinking (Derrida, 2001; Lyotard, 1984, 1988; Poster, 1989). In this context, Honneth (1995) indicates the notion of asymmetrical obligation 
between people, developed by Derrida on the basis of Levinas, as the only real challenge to modern theories of morality in the Kantian tradition. Whereas postmodern attention towards the particularity of each individual person and their rights to articulate interests and claims recalls Habermas' model of communicative action, asymmetrical obligation counters the Kantian perspective of equal treatment, initiating a unique model of postmodern ethics. The premise of this reversal of Kantian autonomy is that we become ethical beings only in accepting the obligation towards the other, which breaks the egocentrism of interest-oriented action of instrumental reason and the disembodied, abstract dictates of the Kantian categorical imperative. In Derrida, this obligation translates in the ideas of unlimited care and hospitality, and the notion of deferred justice (for an account of hospitality and deferred justice, see Derrida, 1992, 2000, 2001). In the ethical relation described by Levinas $(1969,1985,1998,2006)$, the relation to the other lived as pure exteriority is devoid of any form of intentionality, for the self previously enclosed in the solitude of egoism and selfpreservation is exposed to the other in an asymmetrical relation. Levinas writes that:

The freedom of another could never begin in my freedom, that is, abide in the same present, be contemporary, be representable to me. The responsibility for the other cannot have begun in my commitment, in my decision. The unlimited responsibility in which I find myself comes from the hither side of my freedom, from a 'prior to every memory', 'an ulterior to every accomplishment', from the non-present par excellence, the non-original, the anarchical, prior to or beyond essence. (1998, p. 10)

The essence to which Levinas refers is ontological knowledge, or comprehension of beings in terms of generalisation, identity and universality of concepts. Ontological thinking, or thinking about beings, leaves all irreducibility and singularity outside of the relation established by the thinking subject towards the objects of knowledge: "The work of ontology consists in apprehending the individual not in its individuality but in its generality" (Levinas, 1969, p. 44). According to Levinas, ontology is a philosophy of power, based on the impersonal universality of concepts that turn difference and singularity into sameness. Ontological thinking is in other words a form of impersonal knowledge that predominates over the relation with the concrete other in its singularity, in order for the thinking subject to "comprehend orgrasp it"(Levinas, 1969, p. 46). Although ontological thinking predominates in the tradition of Western philosophy, Levinas finds in the ethical relation with the other an originary form of thinking that 'overflows the capacity of thought' (1969, p. 49), adopting the idea of infinity that Descartes (1993) described in the Third Meditation. The argument of that meditation, aimed at establishing the existence of god by the fact that the idea of the infinite cannot have been generated by a finite being, is turned by Levinas to designate the encounter with the other in the form of irreducible alterity, "the relation with a being that maintains its total exteriority to him who thinks it" $(1969$, p. 50). Following this relation of exteriority in the ethical encounter, the other eludes the self and interrupts the dialectic process of representation, when the other is enveloped into a theme and identity is reaffirmed through the creation of a totality. This passage from the solitude of the thinking self to the sociality that is established with the other encountered in her/his singularity is constituted through language, from the dimension of the said to that of the saying. The two modalities of the saying and the said are explored in Otherwise than Being (Levinas, 1998) in relation to language and temporality, when phenomena emerge in consciousness from the flow of perceptions. Levinas describes experience unfolding in two temporalities, the diachronic and the synchronic. In this latter form of temporality, consciousness organises experience in a coherent flow of past, present and future, and the impressions given to consciousness from the external world are categorised and identified with the use of language. This activity of categorisation, that Levinas defines as thematisation, proceeds from a proclamatory, or kerygmatic, expression: which is to say that to identify a being -to acknowledge a being- is to pronounce a proclamation, the fact that a 
phenomenon is "this as that" (Levinas, 1998, p. 35). With this activity, experience is shaped and organised into categories that belong to the doxa (i.e. the historical and cultural horizon in which the self is situated). This cultural horizon is the said:

Giving to historical languages spoken by people a locus, enabling them to orient or polarise the diversity of the thematised as they choose. (1998, p. 36)

This means that kerygmatic proclamations organise immediate experience into intelligible phenomena that are consequently transmitted in the form of narration in the context of cultural traditions, what Levinas calls the "thematised" (Peperzak, 1989). The other dimension of language, the saying, operates beyond the language of identification and categorisation. In this dimension, diachrony is an event that interrupts the synchronicity of time, the orderly flow of past, present and future, through the encounter with the singularity- or uniqueness- of the other person. This relation between temporality, being and language in the saying and the said is explicated by Levinas in the ambiguity of being thought at the same time as a verb, to be, and the noun indicating a simple being or the totality of beings. When being is expressed as noun, it means that the object of experience is isolated from the flow of time and is fixed in synchronic temporality by consciousness into a theme, concept, category, through the said. However, the presence of verbs in language reveals temporality in terms of process, becoming, event in the saying. Rather than placing the two modes of language into a dialectic opposing relation, requiring a synthesis and a totality in which the two elements would rest, Levinas describes the saying in terms of resonance, a diachronic temporality that allows a phenomenon to appear to consciousness before it is absorbed by the said. In other words, the two elements complement each other, as the saying needs a said in order to be processed by consciousness, but it dwells in the said as an irreducible remainder of difference between the content expressed in the said and what escapes categorisation:

It is only in the said that, in the epos of saying, the diachrony of time is synchronised into a time that is recallable, and becomes a theme. (...) But the signification of saying goes beyond the said. (Levinas, 1998, p. 37)

Here, I understand that the presence of the saying underlying the said challenges the idea of the transparency of language, or the perfect correspondence between word and meaning. Levinas employs this understanding of language to illustrate two modalities of existence, the ontological relation to being expressed in the said, in which meaning is fixed, and the ethical relation to the other that emerges in the saying. The ethical relation is also referred in terms of non-relation, to emphasise the irreducibility of the other to the categories of the self, which brings about the loss of the "Cartesian privilege" of consciousness (Levinas, 1996, p. 60). In other words, when the other is encountered in this modality, the saying is expressed in the form of the uncertainty of open-ended dialogue. In the next section, I will contextualise the two categories of the saying and the said in the field of intercultural research. I contrast the ethical relation described by Levinas to the notion of autonomy that guides the formulation of competence and intercultural responsibility, in other words the formulation of the self in terms of the Cartesian "I think" and characterised by autonomy and self-sufficiency. With this contrast, I bring forward on the one side the notion of responsibility in terms of open-ended dialogue and critical engagement (the saying), and on the other a conception of responsibility understood as tolerance of the other (the said).

\section{The saying and the said: two scenarios of responsibility}

To summarise, the said fixes and establishes meanings, it categorises, enveloping an object of knowledge into a theme, it is speaking about something and not to someone. Language as 
information, the said, expresses the symmetry of self and other in the form of communication of content. In this dimension of the said, after being reduced to the known categories of sameness by the active synthesis of the knowing subject, the other becomes the recipient of the moral action in the form of responsibility, tolerance, sensitivity to cultural difference. On the other hand, the saying is a 'speaking to' in the form of dialogue, when the self does not occupy a central position bestowing meaning on the other. The saying is proximity, commitment of the one for the other (Levinas, 1985). Levinas describes this proximity in terms of vulnerability of the subject destitute of sovereignty as an autonomous, self-sufficient being, and exposed to the other. This encounter with alterity is the unveiling of a physical vulnerability 'from which we cannot slip away' (Butler, 2005, p. 101), grounding our responsibility as ethical beings in presence to the other (Levinas in Robbins, 2001). Levinas (1998) further qualifies this approaching as the uncovering of the one who speaks, a denuding of identity in front of the other, an entering of the diachronic temporalisation that is not actively synthesised by the knowing subject but lived in the experience of exposure as responsibility for the other. Thus, the said and the saying stand for two conceptions of speech: the former represents the transmission of content, or communicative competence; the latter is manifested in the presence of speakers to one another, the response to the singularity of the other when the self is addressed in speech (Blanchot, 1993). I suggest that the notion of language as information needing communicative competence to ensure effective transmission of content, which is prevalent in the notion of intercultural training, is a form of totalisation of meaning (Derrida, 1988), the fact that the intention of the speaking subject is in this way exhausted in the speech act, thus leaving no residue that escapes the transmission of intentional meaning. This totalisation is apparent in the idea of intercultural training, by which the competences required to interpret communicative behaviour as expression of a particular culture and to react with an appropriate response in order to communicate effectively are provided. Such an instrumental understanding of communication is radically challenged by the saying, the relation established in speaking to one another, maintaining an asymmetry that defers the process of consensus and closure of meaning into the totality of being. In this way, using this distinction between the saying and the said, the ethical dimension of intercultural communication emerges as the open-ended character of dialogue, which is foregrounded over the idea of communicative competence as effective transmission of meaning. This main contrast between the two modes of communication of the saying and the said is further illustrated in the way in which they are defined by Levinas in the context of the relation between the self and the other. Whilst in the notion of intercultural competence the self and the other are beings enclosed within their own cultural horizon awaiting reciprocal recognition, in the saying self and other are inter-dependent because dialogue requires interaction between interlocutors, and the passage from the synchronicity of themes and categories to the diachrony of lived time. Thus, ethical responsibility resides in this relation between self and other established in the saying, which Levinas describes as a 'face-to-face' encounter: on the one hand, in the said, the other is reified into a cultural being, on the other hand in dialogue, the other is encountered in their own singularity, uniqueness. As such, the two categories of the saying and the said suggest two scenarios of intercultural interaction that show two different approaches to responsibility, one operating in the dimension of the said and the other in the dimension of the saying.

In the first instance, in the dimension of the said, communication develops on a set of assumptions regarding cultural belonging and identity. In this context, the notion of ethical responsibility is limited to the effortto understand the other as a cultural being and to avoid misunderstanding. In this case, the other is an object of knowledge, not an interlocutor, and responsibility is understood as tolerance of the other by the sovereign subject, the autonomous rational agent of Kantian tradition. In the second instance, in the dimension of the saying, dialogue unfolds in ways that are 
unpredictable and that can question our assumptions about culture, identity and belonging through reciprocal interaction between others. Thus, responsibility is revealed not as a conscious act from a fully bounded, all knowing subject, but as finding oneself in a situation that is not of our making. In this regard, Levinas describes the situation of the self being singled out in his/her uniqueness by the call of the other as the 'originary place of identification' (cited in Robbins, 2001, p. 110), in contrast to being identified according to a principle of individuation based on the fact of belonging to a particular national or cultural group. According to Levinas, the status of the saying and the said in relation to alterity - or otherness - surfaces in its simplest forms in everyday acts of politeness, for instance in the act of being addressed by an other, when the saying resonates briefly in the presence of two interlocutors:

In discourse I have always distinguished, in fact, between the saying and the said. That the saying must bear a said is a necessity of the same order as that which imposes a society with laws, institutions and social relations. But the saying is the fact that before the face I do not simply remain there contemplating it, I respond to it. The saying is a way of greeting the Other, but to greet the Other is already to answer for him. It is difficult to be silent in someone's presence; this difficulty has its ultimate foundation in this signification proper to the saying, whatever is the said. It is necessary to speak of something, of the rain and fine weather, no matter what, but to speak, to respond to him and already to answer for him. $(1985$, p. 88)

Adopting a Levinasian perspective, the ethical aspect of language emerges when the discourse of effectiveness, reliability and performance is superseded by concern for the other qua other.

\section{Conclusion}

Intercultural Responsibility: Saying or Said? A problematic aspect in the formulation of competence in intercultural communication is represented by the emphasis placed on the consciousness of the intercultural speaker, which focuses on the cultural divide between self and other. Communication is examined in reference to awareness of cultural differences and with the use of neutral, scientific vocabulary, expressed in the language employed in intercultural training such as competence, skills, training and effectiveness (e.g. Deardorff, 2006, 2009; Hofstede \& Hofstede, 2004; Spencer-Oatey \& Stadler, 2009). This emphasis on consciousness and on a functional, instrumental understanding of communication influences the ways in which ethical responsibility is understood in intercultural research (e.g. Guilherme et al., 2010). To this end, a challenging prospect for future research is represented by the development of forms of theoretical approaches that bring forward and engage with the partial, contested and situated nature of language. Ultimately, the dynamics underpinning communication cannot be readily translated into a formula with practical applications measured by the reliable testing of competences. Despite current articulations of the critical intercultural speaker (Byram, Guilherme) and the languaging subject (Phipps, Gonzalez) which are increasingly attentive towards the hybrid and shifting nature of the self and the socially constructed nature of language, more theoretical engagement is needed to challenge the reliance on the functionalist paradigm of communication described in Martin and Nakayama (2010), that characterises models of communicative competence and responsibility. However, as Phipps argues (2013), the problematic divide between theoretical explorations of ethical issues on the one side, and empirical research driven by the collection of data according to established methodologies in social research on the other, raises questions that need addressing in the field of intercultural research, particularly in relation to the role of the researcher in eliciting, collecting and analysing data. This ethical issue brings to light another under-theorised aspect of intercultural communication, namely the aporia of praxis between relativism and a politics of presence (MacDonald \& O'Regan, 2012). In other words, critical intercultural theory embraces and celebrates cultural difference whilst also aiming at 
unearthing essentialised truths behind perceived ideological falsifications and hegemonic interpretations. Intercultural discourse thus finds itself posited amidst competing validity claims, each asserting their own truth, but incapable of deciding between them. Instead, in the name of universalised ethics of tolerance, it is obliged to support them all. As a result, the vision of ethics promoted in critical interculturalism relies on the idea that intercultural communication will create a fusion of cultural horizons through the idea of universal tolerance, although critical interculturalists have to face other competing claims, for instance those emanating from visions of cultural purity which reassert nationalistic values and divisive arguments across ethnic, linguistic, cultural and historical lines. As a tentative approach, this reading of Levinas suggests that although we are culturally situated, and our cultural horizon is the first instrument that we use in interpreting the world, the ethical encounter opens up a dialogic dimension of communication that is also critical engagement and concern for the concrete other, rather than simple tolerance towards an abstract 'cultural other'. According to this notion of ethical commitment, human individuals cannot be reduced to members or organs of any given community, in the sense that cultural categorisation and the notion of 'fixing' communication reduce the ethical force of the encounter with the other. To conclude, I suggest that there are a number of factors that need to be accounted for in order to develop an ethical model of intercultural communication that challenges preconceived ideas of the other and of culture. First of all, an appreciation of the interdependence of self and other and an awareness of the complexity of real life in which interactions take place, including ideological constructions of culture and the discursive practices that surround the perception of the other (Dervin, 2011; Holliday, 2011; Kramsch, 2009). Furthermore, a consideration of the power dimensions at play in communication, particularly socio-economic inequality and sociolinguistic competence in the use of a dominant language in intercultural encounters (Blommaert, 1998; Piller, 2011; Scollon \& Scollon, 1995). Finally, an acceptance of uncertainty in the form of responsible engagement with others in dialogue, through the awareness of the position of the self as potential all-knowing subject that silences the other and ignores the "needs, beliefs, feelings, desires, interests, demands, or injustices faced by interlocutors in any event" (Smith, 1997, p. 330). In this last sense, responsible engagement in dialogue demands that the Cartesian presuppositions that underlie IC theory are acknowledged and critiqued by interculturalists. Perhaps, an ethical approach to IC entails taking the risk of meeting the other qua other, without the safety net of cultural categorisation, and at the same time being aware that the encounter with the other does not occur in a vacuum, because we are always positioned within networks of power.

\section{References}

References Adorno, T. W., \& Horkheimer, M. (1997). Dialectic of enlightenment. London and New York, NY: Verso.

Anderson, B. (1991). Imagined communities: Reflections on the origins and spread of nationalism. London and New York, NY: Verso.

Atwell, J. E. (1986). Ends and principles in Kant's moral thought. Dordrecht, Boston, and Lancaster: Martinus Nijhoff.

Barnett, G. A., \& Lee, M. (2002). Issues in intercultural communication. In W. B. Gudykunst \& B. Mody (Eds.), Handbook of international and intercultural communication (pp. 275-290). Thousand Oaks, CA: Sage.

Bauman, Z. (2000). Liquid modernity. Cambridge: Polity. Berardo, K., \& Deardorff, D. K. (2012). Building cultural competence: Innovative activities and models. Sterling, VA: Stylus. 
Blanchot, M. (1993). The infinite conversation. Minneapolis, MN: University of Minnesota Press. Blommaert, J. (1991). How much culture is there in intercultural communication? In J. Blommaert \& J. Verschueren (Eds.), The pragmatics of intercultural communication (pp. 13-33). Amsterdam: John Benjamins.

Blommaert, J. (1998). Different approaches to intercultural communication: A critical survey. Plenary Lecture, University of Bremen. 27-28 February. Retrieved December 13, 2013 from http://www.cie.ugent.be/CIE/blommaert1.htm.

Butler, J. (2005). Giving an account of oneself. New York, NY: Fordham University Press. Byram, M. (2008). From foreign language education to education for intercultural citizenship. Clevedon: Multilingual Matters.

Byram, M., \& Risager, K. (1999). Language teachers, politics and cultures. Clevedon: Multilingual Matters. Byram, M., \& Zarate, G. (1997a). Sociocultural competence in language learning and teaching. Strasbourg: Council of Europe.

Byram, M., \& Zarate, G. (1997b). The socio-cultural and intercultural dimension of language learning and teaching. Strasbourg: Council of Europe.

Cheng, H. (2010). A critical reflection on an intercultural communication workshop: Mexicans and Taiwanese working on the US-Mexico border. In T. K. Nakayama \& R. T. Halualani (Eds.), The handbook of critical intercultural communication (pp. 549-564). Chichester, West Sussex: WileyBlackwell.

Council of Europe. (2001). Common European framework of reference for languages: Learning, teaching, assessment, council of Europe, modern languages division. Strasbourg and Cambridge: Cambridge University Press.

Curtin, M. L. (2010). Coculturation: Toward a critical theoretical framework of cultural adjustment. In T. K. Nakayama \& R. T. Halualani (Eds.), The handbook of critical intercultural communication (pp. 270-285). Chichester, West Sussex: Wiley-Blackwell.

Deardorff, D. K. (2006). Identification and assessment of intercultural competence as a student outcome of internationalization. Journal of Studies in International Education, 10, 241-266. doi:10.1177/1028315306287002

Deardorff, D. K. (Ed.). (2009). The SAGE handbook of intercultural competence. London: Sage. Derrida, J. (1992). The other heading: Reflections on today's Europe. Bloomington and Indianapolis: Indiana University Press.

Derrida, J. (1988). Limited Inc. Evanston: Northwestern University Press.

Derrida, J. (2000). Of hospitality. Stanford: Stanford University Press.

Derrida, J. (2001). On cosmopolitanism and forgiveness. Abingdon, Oxon and New York: Routledge. Dervin, F. (2010). Assessing intercultural competence in language learning and teaching: A critical review of current efforts in higher education. In F. Dervin \& E. Suomela-Salmi (Eds.), New approaches to assessing language and (inter-)cultural competences in higher education (pp. 157174). Frankfurt: Peter Lang.

Dervin, F. (2011). A plea for change in research on intercultural discourses: A 'liquid' approach to the study of the acculturation of Chinese students. Journal of multicultural discourses, 6, $37-52$. doi:10.1080/17447143.2010.532218 
Descartes, R. (1993). Meditations on first philosophy. Indianapolis: Hackett.

DeTurk, S. (2010). “Quit whining and tell me about your experiences!”: (In)tolerance, pragmatism, and muting in intergroup dialogue. In T. K. Nakayama \& R. T. Halualani (Eds.), The handbook of critical intercultural communication (pp. 565-584). Chichester: Wiley-Blackwell.

Furrow, D. (2005). Ethics: Key concepts in philosophy. London and New York, NY: Continuum. Gudykunst, W. B. (Ed.). (2003). Cross-cultural and intercultural communication. Thousand Oaks, CA: Sage.

Guilherme, M. (2002). Critical citizens for an intercultural world. Clevedon: Multilingual Matters. Guilherme, M. (2010). Mobility, diversity and intercultural dialogue in the cosmopolitan age. In M. Guilherme, E. Glaser, \& M. del Carmen Méndez Garcia (Eds.), The intercultural dynamics of multicultural working (pp. 1-17). Bristol: Multilingual Matters.

Guilherme, M., Keating, C., \& Hoppe, D. (2010). Intercultural responsibility: Power and ethics in intercultural dialogue and interaction. In M. Guilherme, E. Glaser, \& M. del Carmen Méndez Garcia (Eds.), The intercultural dynamics of multicultural working (pp. 77-94). Bristol: Multilingual Matters. Habermas, J. (1987). The philosophical discourse of modernity. Cambridge: Polity Press.

Hall, W. (1995). Managing cultures: Making strategic relationships work. Chichester, West Sussex: Wiley \& Sons.

Hammer, M. R., Bennett, M. J., \& Wiseman, R. (2003). Measuring intercultural sensitivity: The intercultural development inventory. International Journal of Intercultural relations, 27, 421-443. doi:10.1016/S0147-1767(03)00032-4

Hardcastle, J. (1999). Von Humboldt's children: English and the formation of a European educational ideal. Changing English, 6(1), 31-45. doi:10.1080/1358684990060104

Hofstede, G. (2001). Culture's consequences, comparing values, behaviours, institutions and organisations across nations. Thousand Oaks, CA: Sage.

Hofstede, G., \& Hofstede, G. J. (2004). Cultures and organisations: Software of the mind. New York, NY: McGraw-Hill. Hofstede, G. J., Pedersen, P. B., \& Hofstede, G. (2002). Exploring culture. Yarmouth, ME: Intercultural Press.

Holliday, A. (2011). Intercultural communication and ideology. London: Sage.

Honneth, A. (1995). The other of justice: Habermas and the ethical challenge of post-modernism. In S. K. White (Ed.), The Cambridge companion to Habermas (pp. 289-323). Cambridge: Cambridge University Press.

Hüllen, W. (2006). Foreign language teaching - A modern building on historical foundations. International Journal of Applied Linguistics, 16(1), 2-15. doi:10.1111/j.1473-4192.2006.00103.x

Jack, G. (2009). A critical perspective on teaching intercultural competence in a management department. In A. Feng, M. Byram, \& M. Fleming (Eds.), Becoming interculturally competent through education and training (pp. 95-114). Bristol: Multilingual Matters.

Jacobs, B. (2001). Dialogical rationality and the critique of absolute autonomy. In P. U. Hohendahl \& J. Fisher (Eds.), Critical theory, current state and future prospects (pp. 139-153). New York, NY and Oxford: Berghahn Books. 
Kant, I. (1979). Lectures on ethics. Whitstable, Kent: Methuen.

Kim Yun, Y. (2008). Intercultural personhood: Globalisation and a way of being. International Journal of Intercultural Relations, 32, 337-348. doi:10.1016/j.jintrel.2008.04.003

Kramsch, C. (2009). The multilingual subject. Oxford: Oxford University Press.

Levinas, E. (1969). Totality and infinity. Pittsburgh: Duquesne University Press.

Levinas, E. (1985). Ethics and infinity. Pittsburgh: Duquesne University Press.

Levinas, E. (1996). Proper names. London: Athlone Press. Levinas, E. (1998). Otherwise than being. Pittsburgh: Duquesne University Press.

Levinas, E. (2006). Entre Nous. London and New York, NY: Continuum.

Louhiala-Salminen, L., Charles, M., \& Kankaanranta, A. (2005). English as a lingua franca in nordic corporate mergers: Two case companies. English for specific purposes, 24, 401-421.

doi:10.1016/j.esp.2005.02.003

Lyotard, J. F. (1984). The postmodern condition: A report on knowledge. Manchester: Manchester University Press.

Lyotard, J. F. (1988). The different. Minneapolis: University of Minnesota Press.

MacDonald, M. N., \& O'Regan, J. (2012). The ethics of intercultural communication. Educational Philosophy and Theory, 45, 1005-1017. doi:10.1111/j.1469-5812.2011.00833.x

Martin, J. N., \& Nakayama, T. K. (2010). Intercultural communication and dialectics revisited. In T. K. Nakayama \& R. T. Halualani (Eds.), The handbook of critical intercultural communication (pp. 59-83). Chichester, West Sussex: Wiley-Blackwell.

Monceri, F. (2003). The transculturing self: A philosophical approach. Language and Intercultural Communication, 3, 108-114. doi:10.1080/14708470308668094

Monceri, F. (2009). The transculturing self II: Constructing identity through identification. Language and Intercultural Communication, 9(1), 43-53. doi:10.1080/14708470802444282

Moon, D. G. (2010). Critical reflections on culture and critical intercultural communication. In T. K. Nakayama \& R. T. Halualani (Eds.), The handbook of critical intercultural communication (pp. 34-52). Chichester, West Sussex: Wiley-Blackwell.

Pavlenko, A. (2003). 'Language of the enemy': Foreign language education and national identity. International Journal of Bilingual Education and Bilingualism, 6, 313-331. doi:10.1080/ 13670050308667789

Peperzak, A. (1989). From intentionality to responsibility: On Levinas's philosophy of language. In A. B. Dallery \& C. E. Scott (Eds.), The question of the other (pp. 3-23). Albany: State University of New York Press.

Phipps, A. (2007). Learning the arts of linguistic survival. Languaging, tourism, life. Clevedon: Multilingual Matters.

Phipps, A. (2010). Training and intercultural education: The danger in good citizenship. In M. Guilherme, E. Glaser \& M. del Carmen Méndez Garcia (Eds.), The intercultural dynamics of multicultural working (pp. 59-77). Bristol: Multilingual Matters. 
Phipps, A. (2013). Intercultural ethics: Questions of methods in language and intercultural communication. Language and Intercultural Communication, 13(1), 10-26. doi:10.1080/ 14708477.2012.748787

Phipps, A., \& Gonzalez, M. (2004). Modern languages: Learning and teaching in an intercultural field. London: Sage. Piller, I. (2011). Intercultural communication: A critical introduction. Edinburgh: Edinburgh University Press.

Popke, E. J. (2003). Poststructuralist ethics: Subjectivity, responsibility and the space of community. In Progress in human geography, 27, 298-316. doi:10.1191/0309132503ph429oa

Poster, M. (1989). Critical theory and Post-structuralism in search of a context. Ithaca and London: Cornell University Press.

Risager, K. (2006). Language and culture: Global flows and local complexity. Clevedon: Multilingual Matters.

Risager, K. (2008). Towards a transnational paradigm in language and culture pedagogy. AAAL 2008 Annual Conference, Washington, DC, USA. Retrieved January 3, 2013, from http://www. academia.edu/200448/Towards_a_transnational_paradigm_in_language_and_culture_pedagogy Robbins, J. (Ed.). (2001). Is it righteous to be? Interviews with Emmanuel Levinas. Stanford: Stanford University Press.

Roy, A., \& Starosta, W. J. (2001). Hans-Georg Gadamer, language, and intercultural communication. Language and Intercultural Communication, 1(1), 6-20. doi:10.1080/1470847010866 8060

Schneewind, J. B. (1998). The invention of autonomy: A history of modern moral philosophy. Cambridge: Cambridge University Press.

Scollon, S., \& Scollon, S. W. (1995). Intercultural communication: A discourse approach. Oxford: Blackwell.

Smith, A. R. (1997). The limits of communication: Lyotard and Levinas on otherness. In M. Huspek \& G. P. Radford (Eds.), Communication and the voice of the other (pp. 329-351). New York, NY: Suny Press.

Spencer-Oatey, H., \& Stadler, S. (2009). The global people competency framework: Competencies for effective intercultural interaction. Warwick occasional papers in applied linguistics, 3. Retrieved November 8, 2012, from http://www.globalpeople.org.uk/, http://warwick.ac.uk/al/

Spitzberg, B. H., \& Changnon, G. (2009). Conceptualizing intercultural competence. In D. K. Deardorff (Ed.), The SAGE handbook of intercultural competence (pp. 2-53). London: Sage von Humboldt, W. F. (1988). On language: The diversity of human language-structure and its influence on the mental development of mankind. Cambridge: Cambridge University Press.

Wiseman, R. L. (2003). Intercultural communication competence. In W. B. Gudykunst (Ed.), Crosscultural and intercultural communication (pp. 191-208). Thousand Oaks, CA: Sage. 